Tarbawi: Jurnal Ilmu Pendidikan p-ISSN:1858-1080 | e-ISSN: 2615-6547

Vol. 16, No. 1, Juli 2020, 81 - 94

\title{
Kontribusi Persepsi Siswa tentang Jurusan Terhadap Motivasi Siswa dalam Belajar serta Implikasinya pada Program Bimbingan dan Konseling
}

\author{
Desri Jumiarti \\ Institut Agama Islam Negeri Batusangkar \\ E-mail: desrijumiarti@iainbatusangkar.ac.id
}

\begin{abstract}
Abstrak: Pada sekolah kejuruan, persepsi siswa tentang jurusan yang dipilih diduga merupakan salah satu faktor yang akan mempengaruhi motivasi siswa dalam belajar. Beberapa hasil penelitian telah menjelaskan bahwa persepsi merupakan salah satu faktor internal yang cukup besar pengaruhnya terhadap keberhasilan belajar. Tujuan dari penelitian ini adalah untuk mendeskripsikan persepsi siswa tentang jurusan yang ditempatinya, mendeskripsikan motivasi siswa dalam belajar, dan untuk menguji kontribusi persepsi siswa tentang jurusan terhadap motivasi belajar siswa. Metode yang digunakan dalam penelitian ini adalah kuantitatif jenis deskriptif korelasional. Adapun populasinya yaitu siswa kelas XI SMKN 1 Kota Solok yang berjumlah 580 siswa, sedangkan sampel penelitian berjumlah 237 siswa. Teknik yang digunakan dalam penelitain ini yaitu Proportional Statified Random Sampling. Instrumen yang digunakan adalah angket dengan jenis Likert dengan skala satu sampai lima. Sedangkan analisis data dengan menggunakan statistik deskriptif dan regresi sederhana. Adapun temuan dari penelitian ini adalah: (1) persepsi siswa tentang jurusan yang ditempati rata-rata berada pada kategori positif, (2) motivasi belajar siswa berada pada kategori tinggi, dan (3) terdapat kontribusi yang signifikan antara persepsi siswa tentang jurusan terhadap motivasi belajar siswa. Adapun implikasi dari hasil penelitian ini dapat digunakan untuk menganalisis kebutuhan siswa sebagai penyempurnaan pembuatan program layanan bimbingan dan konseling di SMKN 1 Kota Solok.
\end{abstract}

Kata kunci: Persepsi, Jurusan, Motivasi Belajar, Bimbingan dan Konseling

\begin{abstract}
In vocational schools, students' perceptions about the chosen majors are thought to be one of the factors that will influence student motivation in learning. Several research results have explained that perception is one of the internal factors which has a big influence on learning success. The purpose of this study is to describe student perceptions about the department they occupy, describe student motivation in learning, and to examine the contribution of students' perceptions about majors to student learning motivation. The method used in this research is quantitative descriptive correlational type. As for the population, there are 580th grade students of SMKN 1 Solok. City, while the research sample is 237 students. The technique used in this research is Proportional Statified Random Sampling. The instrument used was a questionnaire with a Likert type on a scale of one to five. Whereas data analysis using descriptive statistics and simple regression. The findings of this study are: (1) students 'perceptions of majors occupied on average are in the positive category, (2) student motivation is in the high category, and (3) there is a significant contribution between students' perceptions of majors towards motivation student learning. The implications of the results of this study can be used to analyze student needs as a refinement of making guidance and counseling service programs in SMKN 1 Solok City.
\end{abstract}

Keywords: Perception, Department, Learning Motivation, Guidance and Counseling 


\section{PENDAHULUAN}

Pendidikan akan menjadikan seseorang untuk belajar secara aktif, lebih mandiri, serta memberdayakan berbagai potensi yang ada pada diri individu tersebut, dan untuk mencapai hal itu salah satunya dapat dilakukan dengan belajar. Keberhasilan siswa dalam belajar dan upaya mengembangkan potensinya dipengaruhi oleh berbagai faktor, antara lain inteligensi, sikap, minat, bakat, dan motivasi siswa. Salah satu faktor yang menjadi penentu keberhasilan siswa dalam belajar adalah motivasi. Pada kegiatan belajar, motivasi akan menjadi suatu penggerak pada diri siswa sehingga akan memunculkan kegiatan belajar, sehingga akan ada proses belajar, dan akan memberi arah pada kegiatan belajar tersebut, sehingga tujuan yang diinginkan subjek tersebut dapat tercapai (Sardiman, 2011).

Siswa yang memiliki motivasi dalam belajar akan mempersiapkan diri dengan baik sebelum belajar, seperti meluangkan waktu belajar lebih banyak, membaca buku pelajaran, mengulang kembali pelajaran, terdorong untuk memulai kegiatan belajar karena keinginan sendiri, tekun dalam belajar, gigih dan tidak merasa putus asa ketika ada kesulitan dalam mengerjakan tugas, menyelesaikan tugas tepat waktu, dan lain-lain, sedangkan siswa yang tidak memiliki motivasi dalam belajar tidak mempersiapkan bahan pelajaran di sekolah dengan baik, mudah putus asa ketika menjumpai kesulitan dalam membuat tugas, tidak mampu mengerjakan pekerjaan rumah, dan tidak tekun mengikuti pelajaran di sekolah.

Berdasarkan hasil penelitian yang dilakukan oleh (Alfith, 2010) tentang "Kontribusi pelaksanaan prakerin dan motivasi belajar siswa terhadap hasil belajar prakerin SMKN 5 Padang", didapatkan hasil bahwa sebanyak 70,28\% siswa memiliki motivasi belajar rendah. Selain itu, penelitian yang dilakukan oleh (Muis, 2009) tentang "Motivasi dan cara belajar peserta didik di kelas unggul dan kelas biasa serta implikasinya terhadap pelayanan bimbingan dan konseling di SMPN 3 Kampar" didapatkan hasil bahwa sebanyak 86,48\% siswa memiliki motivasi belajar rendah. Berdasarkan data dan hasil penelitian tersebut terindikasi bahwa siswa memiliki motivasi belajar yang rendah. Seharusnya siswa memiliki motivasi belajar yang tinggi agar dapat mengikuti proses belajar pembelajaran dengan baik dan mendapatkan hasil belajar yang baik.

Motivasi siswa dalam belajar dipengaruhi oleh banyak faktor, salah satunya adalah persepsi, yaitu dalam hal persepsi siswa tentang jurusan. Hal ini sesuai dengan penelitian yang dapat disimpulkan bahwasanya bagaimana persepsi seseorang tentang sesuatu, hal itu berhubungan langsung dengan perilaku belajar siswa pada saat pembelajaran (Nirwana, 2003). Dengan kata lain, persepsi siswa akan mempengaruhi perilaku siswa dalam belajar, yaitu akan berpengaruh pada semangat maupun motivasi belajar siswa. Selain itu, persepsi merupakan salah satu faktor internal yang cukup besar pengaruhnya terhadap keberhasilan belajar (Daharnis \& Ardi, 2016). Jadi dengan 
kata lain, persepsi siswa yang positif akan berpengaruh pada perilaku siswa dalam belajar. Siswa akan termotivasi dalam belajar jika memiliki persepsi yang positif, dalam hal ini yaitu persepsi siswa tentang jurusan. Jurusan adalah program studi yang dapat ditempati oleh siswa yang akan menentukan keberhasilan siswa (Gani, 1991).

Persepsi yaitu pengalaman seseorang tentang suatu objek peristiwa dan hubungan-hubungan yang diperoleh dengan cara menyimpulkan informasi dan selanjutnya menafsirkan makna informasi tersebut (Rakhmat, 2012). Selain itu, persepsi adalah proses yang melibatkan pengakuan dan interpretasi stimulus pada pikiran (Rookers \& Willson, 2005). Berdasarkan hal ini, persepsi siswa tentang jurusan yaitu bagaimana siswa menilai dan memahami jurusan yang ditempati. Apabila persepsi siswa positif tentang jurusan yang ditempati, maka siswa akan termotivasi dalam belajar. Sebaliknya, apabila persepsi siswa kurang positif tentang jurusan yang ditempati, maka siswa akan kurang termotivasi dalam belajar. Oleh karena itu, persepsi siswa yang positif tentang jurusan yang ditempati sangat diperlukan, karena dengan persepsi yang positif dapat membuat siswa termotivasi dalam belajar, sehingga hasil belajar yang diperolehpun memperoleh hasil yang baik.

Berbicara mengenai persepsi, bahwa objek yang sama tentu akan berbeda jika dipersepsi oleh masing-masing individu. Persepsi dalam diri individu tidak muncul begitu saja, melainkan ada pengaruh dari berbagai faktor. Faktor-faktor itulah yang akan menyebabkan mengapa setiap individu yang melihat sesuatu hal mungkin memberi interpretasi yang berbeda dari apa yang dilihatnya tersebut. Berdasarkan hal tersebut, maka persepsi siswa tentang jurusan dalam penelitian ini adalah penilaian siswa tentang jurusan yang ditempati, yang berkaitan dengan: (1) penilaian siswa tentang suasana pembelajaran, (2) penilaian siswa tentang pentingnya jurusan yang ditempati, dan (3) penilaian siswa tentang prospek karier.

Fenomena yang terjadi harus menjadi perhatian, baik bagi guru mata pelajaran maupun Guru BK/Konselor. Guru BK/Konselor berperan dalam hal pengentasan permasalahan belajar siswa. Pengentasan permasalahan belajar siswa tersebut bisa diupayakan dengan memberikan bantuan berupa layanan-layanan yang ada pada Bimbingn dan Konseling (BK) yang diberikan sesuai dengan permasalahan yang dihadapi siswa. Belum adanya program layanan yang khusus di SMK untuk membantu mengentaskan permasalahan siswa dalam belajar akan mempengaruhi hasil belajar siswa tersebut, sehingga perlu adanya program layanan khusus untuk siswa SMK tersebut, yaitu menyangkut upaya meningkatkan motivasi belajar siswa, dalam hal ini dengan cara menumbuhkan persepsi yang positif pada siswa tentang jurusan yang ditempatinya. Layanan BK ditujukan untuk membantu meningkatkan motivasi belajar siswa yang memiliki motivasi belajar rendah. Pemberian layanan BK juga bertujuan untuk lebih memaksimalkan motivasi siswa dalam belajar. 
Berdasarkan uraian di atas, terlihat adanya kontribusi persepsi siswa tentang jurusan terhadap motivasi belajar siswa. Namun, besar kecilnya kontribusi antara persepsi siswa tentang jurusan terhadap motivasi belajar perlu dilakukan penelitian, karena belum adanya temuan penelitian yang menunjukkan seberapa besar kontribusi antara kedua variabel tersebut serta bagaimana implikasinya pada program bimbingan dan konseling di SMKN 1 Kota Solok.

Sehubungan dengan itu, pengungkapan masalah dalam penelitian ini bertujuan untuk mendeskripsikan persepsi siswa tentang jurusan dan motivasi belajar siswa kelas XI SMKN 1 Kota Solok, serta menguji seberapa besar kontribusi persepsi siswa tentang jurusan terhadap motivasi belajar siswa SMKN 1 Kota Solok. Selain itu, mendeskripsikan program BK kelas XI SMKN 1 Kota Solok Tahun Ajaran 2019/2020 dalam meningkatkan persepsi siswa tentang jurusan dan motivasi belajar siswa di sekolah.

\section{METODE}

Penelitian yang digunakan yaitu metode kuantitatif jenis deskriptif korelasional. Penelitian ini juga menggunakan metode regresi linier sederhana yang bertujuan untuk menguji kontribusi variabel bebas terhadap variabel terikat. Sehubungan dengan jenis penelitian yang digunakan, maka akan dilihat kontribusi antara variabel independen yaitu persepsi siswa tentang jurusan $(X)$ terhadap variabel dependen yaitu motivasi belajar siswa $(Y)$. Populasi penelitian yaitu siswa kelas XI SMKN 1 Kota Solok sebanyak 580 siswa, sampel sebanyak 237 siswa, dipilih dengan cara teknik proportional stratified random sampling. Instrumen yang digunakan adalah angket dengan jenis Likert dengan skala satu sampai lima. Data dianalisis dengan cara statistik deskriptif dan regresi sederhana. Analisis data dibantu dengan menggunakan program SPSS versi 23.00. Data penelitian dianalisis dengan menggunakan teknik deskriptif, selanjutnya pengujian persyaratan analisis, dan kemudian pengujian hipotesis dengan teknik analisis data regresi. Kemudian, dilakukan pembahasan mengenai hasil analisis tersebut. Pembahasan dilakukan untuk memberi makna terhadap hasil analisis yang dilakukan

\section{HASIL}

\section{Deskripsi Data}

Data dalam penelitian ini meliputi variabel persepsi siswa tentang jurusan $(\mathrm{X})$ dan motivasi belajar siswa $(\mathrm{Y})$. 
Deskripsi Data Persepsi Siswa tentang Jurusan (X)

Deskripsi data persepsi siswa tentang jurusan yang berjumlah 237 responden dapat dilihat pada Tabel 1.

Tabel 1. Deskripsi Rata-rata (Mean) dan Persentase (\%) Persepsi Siswa tentang Jurusan $\left(\mathrm{X}_{2}\right)$ Berdasarkan Indikator

\begin{tabular}{clcccccccc}
\hline No. & \multicolumn{1}{c}{ Skor } \\
\cline { 2 - 9 } & \multicolumn{1}{c}{ Indikator } & Ideal & Max & Min & \multicolumn{1}{c}{ Mean } & \% & Sd. & Ket. \\
\hline 1 & $\begin{array}{l}\text { Penilaian siswa } \\
\text { tentang suasana } \\
\text { pembelajaran (15) }\end{array}$ & 75 & 74 & 43 & 14270 & 60,21 & 80,28 & 6 & $\mathrm{P}$ \\
2 & $\begin{array}{l}\text { Penilain siswa tentang } \\
\text { pentingnya jurusan } \\
\text { yang ditempati (14) }\end{array}$ & 70 & 67 & 36 & 12906 & 54,46 & 77,79 & 5,82 & $\mathrm{P}$ \\
$\begin{array}{l}\text { Penilaian siswa } \\
\text { tentang prospek } \\
\text { karier (6) }\end{array}$ & 30 & 30 & 12 & 5546 & 23,40 & 78 & 3,13 & $\mathrm{P}$ \\
Keseluruhan (35) & 175 & 165 & 103 & 32722 & 138,1 & 78,90 & 11,62 & $\mathrm{P}$ \\
\hline
\end{tabular}

Tabel 1 memperlihatkan bahwa, dari keseluruhan indikator siswa mempunyai persepsi yang positif $(\mathrm{P})$ tentang jurusan yang ditempati dengan persentase $78,90 \%$ dari skor ideal. Hal ini juga dapat dilihat dari hasil analisis data setiap indikator, antara lain: penilaian siswa tentang suasana pembelajaran dengan persentase $80,28 \%$, penilaian siswa tentang pentingnya jurusan yang ditempati dengan persentase $77,79 \%$, dan penilaian siswa tentang prospek karier dengan persentase $78 \%$, yang berarti semua berada pada kategori positif $(\mathrm{P})$. Artinya, rata-rata persepsi siswa tentang jurusan yang ditempati berada pada kategori positif $(\mathrm{P})$.

\section{Deskripsi Data Motivasi Belajar Siswa (Y)}

Deskripsi data motivasi belajar siswa yang berjumlah 237 responden dapat dilihat pada Tabel 2 .

Tabel 2. Deskripsi Rata-rata (Mean) dan Persentase (\%) Motivasi Belajar Siswa (Y) Berdasarkan Indikator

\begin{tabular}{cccccccccc}
\hline No. & \multicolumn{10}{c}{ Skor } \\
\cline { 2 - 10 } & \multicolumn{1}{c}{ Indikator } & Ideal & Max & Min & $\sum$ & Mean & $\%$ & Sd. & Ket. \\
\hline 1 & $\begin{array}{l}\text { Ketertarikan dalam } \\
\text { belajar (8) }\end{array}$ & 40 & 40 & 24 & 7684 & 32,42 & 81,1 & 3,201 & $\mathrm{~T}$ \\
2 & $\begin{array}{l}\text { Senang dengan tugas } \\
\text { yang menantang (10) }\end{array}$ & 50 & 49 & 23 & 8810 & 37,17 & 74,3 & 5,77 & $\mathrm{~T}$ \\
3 & $\begin{array}{l}\text { Harapan untuk } \\
\text { berprestasi dalam } \\
\text { belajar (4) }\end{array}$ & 20 & 20 & 9 & 3548 & 15 & 74,85 & 2,51 & $\mathrm{~T}$ \\
4 & $\begin{array}{l}\text { Ketekutan dalam } \\
\text { belajar (12) }\end{array}$ & 60 & 58 & 28 & 10467 & 44,16 & 73,61 & 5,979 & $\mathrm{~T}$ \\
Keseluruhan (34) & 170 & 160 & 100 & 30509 & 128,7 & 75,72 & 14,61 & $\mathrm{~T}$ \\
\hline
\end{tabular}


Tabel 2 memperlihatkan bahwa, dari keseluruhan indikator tingkat motivasi siswa dalam belajar berada pada kategori tinggi ( $\mathrm{T}$ ) dengan persentase 75,72\% dari skor ideal. Hal ini juga dapat dilihat dari hasil analisis data setiap indikator, antara lain: ketertarikan dalam belajar dengan persentase $81,1 \%$, senang dengan tugas yang menantang dengan persentase $74,3 \%$, harapan untuk berprestasi dalam belajar dengan persentase $74,85 \%$, dan ketekunan dalam belajar dengan persentase 73,61\%, yang berarti semua berada pada kategori tinggi (T). Artinya, rata-rata motivasi belajar siswa berada pada kategori tinggi $(\mathrm{T})$.

\section{Deskripsi Data Implikasi Program BK Kelas XI di SMKN 1 Kota Solok Tabun Ajaran 2019/2020}

Mengetahui program BK kelas XI yang ada di SMKN 1 Kota Solok tahun ajaran 2019/2020, peneliti melakukan wawancara dengan dua orang Guru BK/Konselor SMKN 1 Kota Solok pada tanggal 11 Oktober 2019. Hal ini dilakukan untuk melihat bagaimana program BK yang ada di SMKN 1 Kota Solok, sehingga dari hasil penelitian bisa dijadikan acuan serta need assessment oleh Guru BK/Konselor dalam penyempurnaan program BK yang ada di SMKN 1 Kota Solok.

\section{Pengujian Persyaratan Analisis Data}

Uji persyaratan analisis yang dilakukan pada data penelitian ini adalah uji normalitas, uji linieritas, dan uji multikolinieritas.

\section{Uji Normalitas}

Pengujian normalitas dilakukan dengan menggunakan metode Kolmogorov-Smirnov, yang mana jika Asymp. Sig. atau P-value $\geq 0.05$ (taraf signifikansi), maka data berasal dari populasi yang berdistribusi normal. Hasil perhitungan uji normalitas ketiga variabel tersebut disajikan pada Tabel 3.

\section{Tabel 3. Hasil Uji Normalitas}

\begin{tabular}{cccc}
\hline Variabel & Asymp. Sig. & Sig. & Ket. \\
\hline X & 0,200 & 0,05 & Normal \\
Y & 0,200 & & Normal \\
\hline
\end{tabular}

Berdasarkan Tabel 3 dapat disimpulkan bahwa, data kedua variabel tersebut berdistribusi normal. Hal ini menunjukkan bahwa, sudah terpenuhinya salah satu syarat untuk analisis regresi. 


\section{Uji Linieritas}

Uji linieritas dalam penelitian ini memanfaatkan program SPSS versi 23.00. (Yusuf, 2013) menjelaskan "Apabila nilai $\mathrm{F}$ yang diteliti lebih besar dari nilai $\mathrm{F}$ tabel pada taraf signifikansi $(\alpha)=$ 0,05, maka dapat dinyatakan linier". Hasil analisis data dapat dilihat pada Tabel 4.

Tabel 4. Hasil Uji Linieritas Persepsi Siswa tentang Jurusan (X) terhadap Motivasi Belajar Siswa (Y)

\begin{tabular}{cccc}
\hline Variabel & F & Sig. & Ket. \\
\hline XY & 43,127 & 0,000 & Linier \\
\hline
\end{tabular}

Berdasarkan hasil uji linieritas, didapatkan hasil bahwa persepsi siswa tentang jurusan terhadap motivasi belajar siswa linier dengan $\mathrm{F}_{\text {hitung }}(43,127)>\mathrm{F}_{\text {tabel }}(3.89)$.

\section{Pengujian Hipotesis Penelitian}

Kontribusi Persepsi Siswa tentang Jurusan terbadap Motivasi Belajar Siswa

Hasil analisis kontribusi persepsi siswa tentang jurusan terhadap motivasi belajar siswa dapat dilihat pada Tabel 5 .

Tabel 5. Hasil Analisis Regresi Sederhana dan Uji Signifikansi X terhadap Y

\begin{tabular}{cccc}
\hline Variabel & R & $\boldsymbol{R}$ Square & Sig. \\
\hline $\mathrm{X}-\mathrm{Y}$ & 0,395 & 0,156 & 0,000
\end{tabular}

Pada Tabel 5 dapat dilihat bahwa nilai $\mathrm{R}$ sebesar 0,395, berarti hal ini menunjukkan adanya koefisien korelasi antara kedua variabel terbut, dengan taraf signifikan 0,000 . Nilai $R$ Square $\left(R^{2}\right)$ sebesar 0,156, ini berarti 15,6\% besarnya kontribusi persepsi siswa tentang jurusan terhadap motivasi belajar siswa, sedangkan sisanya $84,4 \%$ dijelaskan oleh variabel lain.

\section{PEMBAHASAN}

\section{Persepsi Siswa tentang Jurusan}

Berdasarkan hasil penelitian menunjukkan bahwa, persepsi siswa tentang jurusan secara ratarata keseluruhan berada pada kategori positif. Masing-masing setiap indikator diketahui memperoleh capaikan pada kategori positif yaitu indikator penilaian siswa tentang suasana pembelajaran, penilaian siswa tentang pentingnya jurusan yang ditempati, dan penilaian siswa tentang prospek karier. Hasil analisis data untuk indikator penilaian siswa tentang suasana pembelajaran dengan persentase paling tinggi dari indikator lain. 
Siswa mampu memiliki persepsi yang positif tentang jurusan tidaklah terjadi begitu saja. Hal itu tentunya butuh proses setelah siswa berada di jurusan yang ditempati. Butuh proses yang panjang untuk sampai pada keutuhan persepsi. Sebagaimana dijelaskan bahwa persepsi individu tentang sesuatu bukan hanya berasal dari tindakan mental, namun melibatkan proses yang panjang dimulai dari mengenali, mengorganisasikan, sampai pada memahami respon melalui tangkapan indera yang diterima dari lingkungan sekitar (Sternberg, 2008).

Pencapaian yang positif pada semua indikator memperlihatkan bahwa, persepsi siswa tentang jurusan yang ditempati sudah baik. Selain itu, Pencapaian dengan persentase yang lebih tinggi pada indikator penilaian siswa tentang suasana pembelajaran memperlihatkan bahwa siswa butuh suasana pembelajaran yang baik dan menyenangkan agar tercipta persepsi yang positif tentang jurusan yang ditempati. Hal ini terdapat pada item instrumen Nomor 1, 2, 3, dan 6 yaitu ketika suasana belajar menyenangkan, mata pelajaran yang diikuti menyenangkan, dan siswa merasa mata pelajaran yang diikuti tersebut bermanfaat untuk dirinya, maka hal ini secara tidak langsung akan menciptakan persepsi yang positif pada diri siswa tentang jurusan yang ditempati. Persepsi adalah suatu proses kognitif yang dialami oleh individu dalam memahami suatu informasi tentang lingkungannya, baik itu melalui pendengaran, penghayatan, penglihatan, penciuman, maupun perasaan (Thoha, 2007).

Berdasarkan hasil penelitian dan paparan yang sudah dijelaskan, dapat ditarik kesimpulan bahwa persepsi siswa tentang jurusan sudah positif. Walaupun persepsi siswa sudah positif tentang jurusan, peran Guru BK/Konselor tetap diperlukan. Guru BK/Konselor tetap selalu bekerja sama dengan orangtua dan pihak sekolah untuk terus meningkatkan persepsi yang positif pada diri siswa tentang jurusan yang ditempati. Selain itu, Guru BK/Konselor bekerja sama dengan guru mata pelajaran untuk dapat meningkatkan persepsi yang positif tentang jurusan yang ditempati siswa, misalnya dengan menciptakan suasana pembelajaran yang menyenangkan, membuat siswa merasa mata pelajaran yang diikuti menyenangkan dan bermanfaat untuk dirinya, sehingga dapat membuat siswa memiliki persepsi yang positif tentang jurusan yang ditempati. Dengan demikian, persepsi siswa tentang jurusan yang ditempati menjadi lebih positif lagi.

Dalam hal ini Guru BK/Konselor mempunyai peranan penting agar dapat mempertahankan dan terus mengembangkan persepsi siswa tentang jurusan yang ditempatinya semakin lebih positif lagi. Dengan demikian, data hasil penelitian ini bisa dijadikan untuk analisis kebutuhan siswa oleh Guru BK/Konselor. Dari analisis kebutuhan inilah maka Guru BK/Konselor dapat dijadikan bahan untuk membuat program BK. Sehingga Guru BK/Konselor dapat mengembangkan persepsi siswa tentang jurusan yang ditempati menjadi lebih positif lagi. Jika hal ini terus dilakukan 
secara berkesinambungan, maka siswa akan merasakan dampaknya, sehingga secara tidak langsung dapat membentuk motivasi belajar siswa.

\section{Motivasi Belajar Siswa}

Berdasarkan hasil penelitian menunjukkan bahwa, motivasi belajar siswa secara rata-rata keseluruhan berada pada kategori tinggi. Hal ini dapat dipahami bahwa adanya ketertarikan siswa dalam belajar, senang dengan tugas yang menantang, mempunyai harapan untuk berprestasi dalam belajar, serta memiliki ketekunan dalam belajar.

Selain itu, pencapaian dengan persentase yang lebih tinggi pada ketertarikan dalam belajar memperlihatkan bahwa siswa akan termotivasi untuk belajar jika siswa tertarik dengan apa yang akan dipelajari. Hal ini terdapat pada item instrumen Nomor 1, 2, 3, 4, dan 5 yaitu ketika siswa tertarik dalam belajar maka siswa akan termotivasi dalam belajar, sehingga akan muncul keinginan untuk belajar dan berusaha untuk memperhatikan guru ketika menerangkan pelajaran. Siswa yang memiliki ketertarikan dalam belajar akan meningkatkan kemampuan mereka untuk menunjukkan tingkah laku yang mendorong untuk berusaha, ketekunan, dan pencapaian prestasi (Schunk, Pintrink, \& Meece, 2008).

Berdasarkan hasil analisis deskriptif menunjukkan bahwa motivasi siswa dalam belajar pada kategori tinggi, namun tetap perlu ditindaklanjuti. Guru BK/Konselor, orangtua, maupun pihak sekolah khususnya guru mata pelajaran bekerjasama untuk terus meningkatkan motivasi siswa dalam belajar seperti dengan cara membuat siswa tertarik dalam belajar, agar nantinya motivasi belajar siswa terus meningkat.

Dengan demikian, data hasil penelitian ini bisa dijadikan untuk analisis kebutuhan siswa oleh Guru BK/Konselor. Dari analisis kebutuhan inilah maka Guru BK/Konselor dapat dijadikan bahan untuk membuat program BK. Sehingga Guru BK/Konselor dapat terus meningkatkan motivasi siswa dalam belajar menjadi lebih tinggi lagi.

\section{Kontribusi Persepsi Siswa tentang Jurusan terhadap Motivasi Belajar Siswa}

Hasil penelitian menunjukkan persepsi siswa tentang jurusan terhadap motivasi belajar siswa berkontribusi secara signifikan. Perolehan ini didapat berdasarkan ananlisis data bahwasanya kontribusi kedua variabel tersebut adalah sebesar 15,6\%. Artinya, persepsi siswa tentang jurusan merupakan salah satu faktor yang berkontribusi terhadap motivasi belajar siswa.

Bedasarkan dari data penelitian, dapat dipahami bahwasanya semakin positif persepsi siswa tentang jurusan, maka semakin tinggi pula motivasi siswa dalam belajar. Hal ini terlihat pada item instrumen persepsi siswa tentang jurusan nomor 28 yaitu, "Bagaimanapun sulitnya mata pelajaran 
yang saya hadapi, saya sudah yakin dengan jurusan yang saya tempati" secara rata-rata jawaban siswa positif. Persepsi siswa tentang jurusan tersebut sejalan dengan capaian item instrumen motivasi belajar siswa nomor 22 yaitu, "Saya berusaha untuk bisa mendapatkan hasil belajar yang bagus" secara rata-rata tinggi. Hal tersebut menjadi bukti salah satu bahwa persepsi siswa tentang jurusan sangat menentukan tinggi rendahnya motivasi siswa dalam belajar.

Berdasarkan hasil penelitian tersebut, dapat dipahami bahwa begitu berpengaruhnya persepsi siswa tentang jurusan dalam menentukan motivasi belajar siswa. Seberapa besar motivasi belajar siswa salah satunya dipengaruhi oleh persepsi siswa tentang jurusan yang ditempati. Jika persepsi siswa positif tentang jurusan yang ditempati, maka siswa akan lebih semangat dalam belajar.

Hal ini sesuai dengan penelitian yang menyatakan bahwa persepsi seseorang tentang sesuatu, hal itu berhubungan langsung dengan perilaku belajar siswa pada saat pembelajaran (Nirwana, 2003). Selain itu persepsi merupakan salah satu faktor internal yang cukup besar pengaruhnya terhadap keberhasilan belajar (Daharnis \& Ardi, 2016). Oleh sebab itu, perlu adanya pemahaman dari Guru BK/Konselor dan guru mata pelajaran bahwasanya agar motivasi belajar siswa terus tumbuh dan berkembang, maka yang perlu dilakukan terlebih dahulu adalah menjadikan persepsi siswa tentang jurusan menjadi lebih positif. Sebagaimana dijelaskan bahwa persepsi ini pula selanjutnya yang secara langsung mempengaruhi perilaku (Siagian, 2004).

Hal yang perlu dilakukan Guru BK/ Konselor untuk menjadikan persepsi siswa menjadi lebih positif lagi adalah dengan memberikan beberapa layananan Bimbingan dan Konseling, sehingga secara langsung akan meningkatkan motivasi belajar siswa, yaitu melalui pemberian layanan orientasi, informasi, bimbingan kelompok, dan konseling perorangan. Selain itu, Guru BK/Konselor dapat bekerja sama dengan orangtua dan pihak sekolah dalam mengembangkan persepsi yang positif pada siswa tentang jurusan yang ditempati. Layanan informasi dapat diberikan oleh Guru BK/konselor kepada siswa, untuk memberikan informasi-informasi mengenai hal-hal yang berkaitan dengan jurusan yang ditempati siswa, sehingga akan membentuk persepsi siswa yang positif tentang jurusan yang ditempati, dan secara tidak langsung dengan siswa memiliki persepsi yang positif pada jurusan yang ditempati dapat meningkatkan motivasi siswa dalam belajar.

Layanan bimbingan kelompok dapat diberikan oleh Guru BK/ Konselor dengan membahas topik-topik tugas yang berkaitan dengan tujuan dan manfaat motivasi belajar siswa. Bimbingan kelompok terbukti efektif untuk mengubah persepsi siswa, sesuai dengan hasil penelitian (Sari, 2015) yang menjelaskan layanan bimbingan kelompok efektif untuk mengubah persepsi siswa berkaitan dengan disiplin belajar.

Selanjutnya, untuk membahas masalah persepsi siswa yang kurang positif tentang jurusan secara pribadi, mendalam, dan spesifik, Guru BK/Konselor dapat melaksanakan layanan konseling 
perorangan. Dalam layanan konseling perorangan memungkinkan siswa membuka diri setransparan mungkin mengenai masalah yang dihadapi, misalnya terkait dengan persepsi yang kurang positif tentang jurusan yang ditempati atau kurangnya motivasi belajar siswa. Dalam suasana seperti itu siswa diibaratkan sedang berkaca (Prayitno, 2012). Melalui keadaan berkaca seperti itu, siswa dapat memahami keadaan diri sendiri maupun lingkungannya mengenai motivasi siswa dalam belajar, sehingga siswa menyadari kelemahan dan kekuatan yang dimilikinya, serta secara nyata siswa mampu mengubah persepsinya menjadi lebih positif tentang jurusan yang ditempati, sehingga motivasi belajar siswa dapat terus ditingkatkan.

Beberapa layanan tersebut merupakan alternatif pelayanan BK yang dapat diberikan oleh Guru BK/Konselor. Selain itu, Guru BK/Konselor dapat bekerja sama dengan orangtua dan pihak sekolah dalam mengembangkan persepsi yang positif pada siswa tentang jurusan yang ditempati. Guru BK/Konselor juga dapat bekerja sama dengan guru mata pelajaran dalam membentuk persepsi siswa yang positif tentang jurusan, seperti guru mata pelajaran dapat menciptakan suasana pembelajaran yang menarik, sehinga siswa memiliki persepsi yang positif tentang jurusan dan secara tidak langsung akan membuat siswa termotivasi dalam belajar. Hal tersebut dalam rangka penanganan persepsi siswa tentang jurusan yang kurang positif, maupun mengembangkan persepsi siswa tentang jurusan yang lebih positif lagi, sehingga motivasi belajar siswa dapat terus ditingkatkan. Adanya persepsi siswa yang positif tentang jurusan, secara langsung dapat menjadikan motivasi siswa dalam belajar terus ditingkatkan.

\section{Keterlaksanaan Program BK Kelas XI di SMKN 1 Kota Solok}

Berdasarkan dari hasil analisis dokumen dan wawancara yang dilakukan dengan Guru BK/Konselor SMKN 1 Kota Solok dapat diketahui bahwa sebagian materi dan pelayanan BK sudah terlaksana dengan baik dalam hal upaya peningkatan persepsi siswa tentang jurusan yang ditempati dan motivasi siswa dalam belajar.

Hal ini sesuai dengan yang dituangkan dalam Peraturan Menteri Pendidikan dan Kebudayaan Republik Indonesia No. 111 Tahun 2014 (Peraturan Menteri Pendidikan dan Kebudayaan, 2014) tentang kegiatan layanan, bahwa layanan bimbingan dan konseling diselenggarakan secara terprogram berdasarkan analisis kebutuhan (need assessment) dan hendaknya hal itu dilaksanakan secara rutin dan berkelanjutan. Dalam hal ini semua siswa harus mendapatkan layanan bimbingan dan konseling secara teratur, sistematis, terencana dan semua layanan yang diberikan tersebut diberikan sesuai dengan kebutuhan siswa. Hal tersebut diperlukan agar pelayanan BK berjalan sesuai dengan yang seharusnya dan layanan yang diberikan sesuai dengan kebutuhan siswa. 


\section{PENUTUP}

Berdasarkan temuan dan pembahasan hasil penelitian, maka dapat disimpulkan bahwa persepsi siswa tentang jurusan di SMKN 1 Kota Solok rata-rata berada pada kategori positif, motivasi belajar siswa di SMKN 1 Kota Solok rata-rata berada pada kategori tinggi, persepsi siswa tentang jurusan memberikan kontribusi secara signifikan terhadap motivasi belajar siswa di SMKN 1 Kota Solok yaitu sebesar 15,6\%, pada program BK kelas XI SMKN 1 Kota Solok Tahun Ajaran 2019/2020, materi yang berkaitan dengan persepsi siswa tentang jurusan dan motivasi belajar siswa sebagian telah terkandung dan tertulis di dalam program, namun belum mencakup secara keseluruhan, sehingga dari hasil penelitian yang peneliti lakukan dapat dijadikan sebagai analisis kebutuhan siswa untuk penyempurnaan pembuatan program pelayanan BK di SMKN 1 Kota Solok. Berdasarkan hasil penelitian ini agar dapat dijadikan dasar serta pedoman untuk penelitian lanjutan dengan memperluas variabel serta subjek penelitian, seperti dikembangkan penelitian pada variabel-variabel independen lain yang diduga berkontribusi terhadap motivasi belajar siswa, sehingga memperdalam, memperjelas, dan memberikan temuan yang terbaru terkait dengan motivasi belajar siswa.

\section{REFERENSI}

Alfith. (2010). Kontribusi Pelaksanaan Prakerin dan Motivasi Belajar Siswa terbadap Hasil Belajar Prakerin SMKN 5 Padang. Program Studi Bimbingan dan Konseling Pascasarjana UNP.

Daharnis, D., \& Ardi, Z. (2016). the Compatibility Student Choice of University Majoring; a Preliminary Studies. GUIDEN A: Jurnal Ilmu Pendidikan, Psikologi, Bimbingan Dan Konseling, 6(1), 101. https://doi.org/10.24127/gdn.v6i1.440

Gani, R. A. (1991). Bimbingan Penjurusan. Angkasa.

Muis. (2009). Motivasi dan Cara Belajar Peserta Didike Kelas Unggul dan Kelas Biasa serta Implikasinya terhadap Pelayanan Bimbingan dan Konseling Di SMPN 3 Kampar. Program Studi Bimbingan dan Konseling Pascasarjana UNP.

Nirwana, H. (2003). Hubungan Tingkat Aspirasi dan Persepsi tentang Belajar dengan Hasil Belajar Matematika Siswa SMU yang Berlatarbelakang Budaya Minangkabau dan Batak. Program Pascasarjana Universitas Negeri Malang.

Peraturan Menteri Pendidikan dan Kebudayaan. (2014). Peraturan Menteri Pendidikan dan Kebudayaan Nomor 111 tabun 2014 Tentang Bimbingan dan Konseling pada Pendidikan Dasar dan Menengah. 138.

Prayitno. (2012). Jenis Layanan dan Kegiatan Pendukung Konseling. FIP UNP.

Rakhmat, J. (2012). Psikologi Komunikasi. Remaja Karya.

Rookers, P. \& Willson, J. (2005). Perception: Theory, development, and organisation. Taylor \& Francis eLibrary.

Sardiman, A. M. (2011). Interaksi dan Motivasi Belajar Mengajar. Raja Grafindo Persada.

Sari, I. L. (2015). Efektivitas Layanan Bimbingan Kelompok dalam Mengubah Persepsi Siswa tentang Disiplin di Sekolah. Program Studi S2 Bimbingan dan Konseling Fakultas Ilmu Pendidikan Universitas Negeri Padang. 
Schunk, D. H., Pintrink, P. R., \& Meece, J. L. (2008). Motivation in Education: Theory, research, and applications. Pearson Education.

Siagian, S. P. (2004). Teori Motivasi dan Aplikasinya. Rineka Cipta.

Abid, M. ., Kanwal, S., Nasir, M. A. ., Iqbal, S., \& Huda, N. . (2016). The Effect of Locus of Control on Academic Performance of the Students at Tertiary level. International Review of Management and Business Research, 5(3), 860-869.

Angelova, N. (2016). Locus of control and its relationship with some social-demographic factors. Psychological Thought, 9, 248-258. https://doi.org/10.5964/psyct.v9i2.179

Bar-Tal, D., \& Bar-Zohar, Y. (1977). The relationship between perception of locus of control and academic achievement: Review and some educational implications. Contemporary Educational Psychology, 2(2), 181-199. https://doi.org/https://doi.org/10.1016/0361-476X(77)90020-0

Bulut Serin, N., Serin, O., \& Șahin Kuralp, F. S. (2010). Factors affecting the locus of control of the university students. Procedia - Social and Behavioral Sciences, 2, 449-452. https://doi.org/10.1016/j.sbspro.2010.03.041

Cohen, M., \& Azaiza, F. (2007). Health-promoting behaviors and health locus of control from a multicultural perspective. Ethnicity \& Disease, 17(4), 636-642.

Dada, O. ., \& Fagbemi, O. . (2018). Influence of Emotional Intelligence and Locus of Control on Academic Achievement of Underachieving High Ability Students. Journal for the Education of Gifted Young, 6(2), 14-22.

Fini, A. A. S., \& Yousefzadeh, M. (2011). Survey on Relationship of Achievement Motivation, Locus of Control and Academic Achievement in High School Students of Bandar Abbas (Iran). Procedia - Social and Behavioral Sciences, 30, 866-870. https://doi.org/https://doi.org/10.1016/j.sbspro.2011.10.168

Geist, C. R., \& Bangham, W. R. (1980). Locus of Control and Religious Affiliation. Psychological Reports, 47(3_suppl), 1281-1282. https://doi.org/10.2466/pr0.1980.47.3f.1281

Ghasemzadeh, A., \& saadat, M. (2011). Locus of Control in Iranian University Student and I's Relationship with Academic Achievement. Procedia - Social and Behavioral Sciences, 30, 24912496. https://doi.org/https://doi.org/10.1016/j.sbspro.2011.10.486

Knott, C., Roth, D., Huang, J., \& Clark, E. (2015). Gender Differences in the Roles of Religion and Locus of Control on Alcohol Use and Smoking Among African Americans. Journal of Studies on Alcohol and Drugs, 76, 482-492. https://doi.org/10.15288/jsad.2015.76.482

Lal, B. (1985). Relationship Between Sex Differences in Locus of Control and Job Performance in Library Organizations. Annals of Library Science and Documentation, 31(3-4), 76-79.

Mamlin, N., Harris, K. R., \& Case, L. P. (2001). A methodological analysis of research on locus of control and learning disabilities: Rethinking a common assumption. The Journal of Special Education, 34(4), 214-225. https://doi.org/10.1177/002246690103400404

Mohamed, A. ., Mohammed, A. ., \& Ahmed, H. . (2018). Relation Between Locus of Control and Academic Achievement of Nursing Students at Damanhour University. IOSR Journal of Nursing and Health Science, 7(5), 1-13.

Rotter, J. B. (1966). Generalized expectancies for internal versus external control of reinforcement. In Psychological Monographs: General and Applied (Vol. 80, Issue 1, pp. 1-28). American Psychological Association. https://doi.org/10.1037/h0092976

Rotter, J. B. (1990). Internal Versus External Control of Reinforcement. American Psychologist, 45(4), 489-493.

Salehi, L., Solimanzadeh, L., Yazdi, S., \& Abbaszadeh, A. (2007). The Relationship between Religious Beliefs and Locus of Control with Mental Health. The Journal of Qazvin Univ of Med. Sci, 11(1), 50-55.

Septiani, Y. (2017). Pengaruh Locus Of Control terhadap Prestasi Belajar Matematika. JKPM (Jurnal Kajian Pendidikan Matematika), 2, 118. https://doi.org/10.30998/jkpm.v2i1.1898

Shannak, R., \& Al-Taher, A. (2012). Factors affecting Work Locus of Control: An Analytical and Comparative Study. Jordan Journal of Business Administration, 8, 373-389. 
Shrauger, J. S., \& Silverman, R. E. (1971). The Relationship of Religious Background and Participation to Locus of Control. Journal for the Scientific Study of Religion, 10(1), 11-16. https://doi.org/10.2307/1385313

Stipek, D. (1980). A causal analysis of the relationship between locus of control and academic achievement in first grade. Contemporary Educational Psychology, 5(1), 90-99. https://doi.org/https://doi.org/10.1016/0361-476X(80)90029-6

Sujadi, E. (2019). Penerapan Play Therapy dengan Menggunakan Permainan Tradisional untuk Meningkatkan Keterampilan Sosio Emosional. Jurnal Bimbingan Dan Konseling Terapan, 3(1), 14-24. https://doi.org/https://doi.org/10.30598/jbkt.v3i1.892

Sujadi, Eko. (2018). Kode Etik Profesi Konseling Serta Permasalahan dalam Penerapannya. Tarbawi: Jurnal Ilmu Pendidikan, 14(2), 69-77. https://doi.org/10.32939/tarbawi.v14i2.298

Sternberg, R. J. (2008). Psikologi Kognitif Edisi Keempat. Terjemahan oleh Yudi Santoso. Pustaka Pelajar. Thoha, M. (2007). Perilaku Organisasi: Konsep dasar dan aplikasinya. Rajawali Pers.

Yusuf, A. M. (2013). Metode Penelitian Kuantitatif, Kualitatif, dan Penelitian Gabungan. UNP Press. 